\title{
REGISTRATION REQUIREMENTS FOR APPLICATION RIGHTS
}

\author{
Desi RatnaSari \\ 155100017 \\ Fakultas Komputer, 448757184 \\ Desiratnasari.student@umitra.ac.id
}

\begin{abstract}
Intellectual works that are aesthetic creations such as copyright and industrial design are relatively easy to obtain patent rights. Including the discovery of computer program methods, presentations on information found were easier to obtain patent licenses. Even so, there are also intellectual works that apparently cannot be patented. Here are intellectual works that cannot be patented:

If the other party obtaining the transfer of rights from the inventor will have a patent for 20 years from the first day of the date of receipt. The rest, after 20 years the exclusive rights will become a public domain. Public domains are intended for the general public, of course, they continue to process licenses to patent holders. Patent rights in intellectual property rights have territorial principles.

The territorial principle in this case the patent rights only applies in the country of the inventor submitting a patent application and given. Submissions are made by sending a letter of request to the Director General of Intellectual Property Rights (DJHKI). If the inventor obtains patent rights in Indonesia, for example, the patent rights obtained are not valid or do not have patent rights in other countries.

The obligation of the inventor to obtain patent rights has the right to pay an annual fee. The fee is part of the cost of maintaining the patent up to the last year of the protection period. Patents will be legally lost if not paid for three consecutive years. The cost of maintaining patent rights is determined by PNBP Non-Tax State Revenues at the Ministry of law and human rights.
\end{abstract}

Keywords: Invertor Obligations, PNBP and HAM

\section{A. INTRODUCTION}

Intellectual Property Rights

(IPR) are important to confirm

the findings of the lecturers.

One of the safeguards of
Intellectual Property Rights is

to patent the findings. In the general public interpreting Intellectual Property Rights and Patents are understood as the same term. Patent of one part 
of Intellectual Property Rights or Intellectual Property Rights which functions to protect the intellectual work of lecturers, students and the general public who produce works. Various intellectual works, ranging from technological (invention), research, art and much more. One example of an inventive intellectual work that can be patented can be products and processes. For example the discovery of a tool to measure $\mathrm{pH}$ levels in water to determine the normal levels for plants.

\section{INTELLECTUAL WORKING TERMS THAT CAN BE PASSED}

Categories of works and inventions can be patented based on certain characteristics. In other words, not all inventions can be patented. Works / inventions that can be patented must fulfill substantive requirements. Substantively divided into two things as follows.

New

The results of intellectual work have never been published before. Both are published in any media. The steps that must be taken care of in order to obtain a patent, by submitting an application. After submitting an application, the date of receipt will be obtained. If intellectual work is published before obtaining the date of receipt, the application can fail.

Inventive The principle of obtaining an IPR patent is inventive, or the ability to create, design something that has never existed before. Patents only given to intellectual work are only given to inventors who have skilled in the art persons.

Applicative

Applicative intentions of the results of the research found can be done repeatedly. Can also be interpreted as having a level of benefit for the community. The more the findings are used by the wider community, indicating that the findings are successful as a solution to the problems that arise. Intellectual work has consistent conditions, not volatile.

Intellectual works that are aesthetic creations such as copyright and industrial design are relatively easy to obtain patent rights. Including the discovery of computer program methods, presentations on information found were easier to obtain patent licenses. Even so, there are also intellectual 
works that apparently cannot be patented. Here are intellectual works that cannot be patented:

Intellectual work does not oppose the rules of Intellectual Property Rights. Among them, do not announce the work before submitting an application letter. Intellectual work does not conflict with applicable laws. The work also does not oppose religious morality, contains RAS and disrupts public order.

Intellectual work is not in the practice of trial and error. Intellectual work does not include methods and theories. For example the method of examination, treatment, care, surgery and treatment. Including mathematical theories and formulas. No matter how great the formula solves the problem, it still cannot be patented.

\section{NOTE OBTAINING PATENT RIGHTS}

Owners of intellectual works are referred to as inventors. Inventor can be done individually or in groups. Inventors find it easier to obtain patent rights for the findings of their intellectual work. Whereas outside the inventor, the inventor must be transferred in writing beforehand.
If the other party obtaining the transfer of rights from the inventor will have a patent for 20 years from the first day of the date of receipt. The rest, after 20 years the exclusive rights will become a public domain. Public domains are intended for the general public, of course, they continue to process licenses to patent holders.

Patent rights in intellectual property rights have territorial principles. The territorial principle in this case the patent rights only applies in the country of the inventor submitting a patent application and given. Submissions are made by sending a letter of request to the Director General of Intellectual Property Rights (DJHKI). If the inventor obtains patent rights in Indonesia, for example, the patent rights obtained are not valid or do not have patent rights in other countries.

The obligation of the inventor to obtain patent rights has the right to pay an annual fee. The fee is part of the cost of maintaining the patent up to the last year of the protection period. Patents will be legally lost if not paid for three consecutive years. The cost of maintaining patent rights is determined by PNBP Non-Tax State Revenues at the Ministry of law and human rights. 
Financing costs consist of principal and claims. The payment period once every year, based on the same date as the first patent application. In other words, the deadline for payment falls on the same date when filing.

\section{BERSIFAT TIME-SENSITIVE PATENT RIGHTS}

Patent rights are given to the first inventor who submits a patent application. When submitting an application it is crucial and is time-sensitive. In other words, if there are two inventors who have the same intellectual work, what is recognized is that the inventor first submitted the application. Alaxander Graham Bell was named the inventor of the telephone because it was one step faster to register his patent than his competitors at that time.

Patents in intellectual property rights for those who already know, in droves submit a request. The cost of a patent application is Rp. 750,000.00. Even though they are actually still hesitant to confirm it. Interestingly, there are some who do not care about the patent registration fee for intellectual work that is not commercial. They still do not feel loss, because obtaining patents is more important than just economic benefits. Bearing in mind, patents cannot be patented again if they have been published.

\section{PROCEDURE FOR SUBMITTING APPLICATION FOR IPR PATENT RIGHTS}

The requirement to apply for intellectual property rights patent rights is truly renewable. No one has ever filed before. As for how to check whether our work is renewable or not. we can check patent documents in the database of DJHKI and patent offices abroad. For example, checking scientific journals and the like.

If our work is not yet renewable, the next process is to make a patent application proposal. Proposals for filing patents include the title of invention, background of invention, brief description of intellectual work found and technical drawings. Technical drawings accompanied by a brief description. Then equipped with abstracts and claims. This circuit is then called the preparation of patent specifications.

Patent specifications as a minimum requirement that must be included. The three conditions must be met to obtain a filing date, among which are fulfilling patent specifications, application forms and registration fees. As for other requirements as a formality, where these 
conditions can be completed for three months after receiving the date of receipt. Following are the requirements for applications that need to be prepared.

1. Declaration of rights

2. Rights transfer

3. Power of attorney

4. Photocopy of the applicant's KTP / identigas

5. Photocopy of Deed of establishment of legalized legal entity

6. Photocopy of NPWP legal entity

7. Photocopy of ID card in the name of the legal entity applicant to sign a statement and power of attorney.

If the above points are complete, the inventor is just waiting for the results from the DJHKI. Announcement will be published publicly after 18 months from the results of the submission. Patent applicants while waiting for the announcement are published in the official news on patents and official media. The goal is to find out about patented intellectual property rights. If the community or outside inventors object because they are deemed not to be eligible for patenting, they can submit in writing to DJHKI.

Especially for rejected inventors, it is permissible to appeal to the Patent Appeal Commission. Later, it will continue to the Commercial Court and appeal to the
Supreme Court. If the inventor submission of patent rights is still rejected, then the results of intellectual property rights will become a public domain. Whereas for those who obtain a patent, they will obtain a patent certificate from DJHKI.

That is a review of the Patent Rights of Intellectual Property (IPR). Given that the terms and conditions for filing IPR patents are quite long, there is an IPR consultant agency. Hopefully this review is useful. Happy work creates intellectual work.

\section{B. CONCLUSION}

The requirement to apply for intellectual property rights patent rights is truly renewable. No one has ever filed before. As for how to check whether our work is renewable or not. we can check patent documents in the database of DJHKI and patent offices abroad. For example, checking scientific journals and the like.

If our work is not yet renewable, the next process is to make a patent application proposal. Proposals for filing patents include the title of invention, background of invention, brief description of intellectual work found and technical drawings. Technical drawings accompanied by a brief description. Then equipped with abstracts and claims. This circuit is then 
called the preparation of patent specifications.

Patent specifications as a minimum requirement that must be included. The three conditions must be met to obtain a filing date, among which are fulfilling patent specifications, application forms and registration fees. As for other requirements as a formality, where these conditions can be completed for three months after receiving the date of receipt. Following are the requirements for applications that need to be prepared.

8. Declaration of rights

9. Rights transfer

10. Power of attorney

11. Photocopy of the applicant's KTP / identigas

12. Photocopy of Deed of establishment of legalized legal entity

13. Photocopy of NPWP legal entity

14. Photocopy of ID card in the name of the legal entity applicant to sign a statement and power of attorney.

If the above points are complete, the inventor is just waiting for the results from the DJHKI. Announcement will be published publicly after 18 months from the results of the submission. Patent applicants while waiting for the announcement are published in the official news on patents and official media. The goal is to find out about patented intellectual property rights. If the community or outside inventors object because they are deemed not to be eligible for patenting, they can submit in writing to DJHKI.

Especially for rejected inventors, it is permissible to appeal to the Patent Appeal Commission. Later, it will continue to the Commercial Court and appeal to the Supreme Court. If the inventor submission of patent rights is still rejected, then the results of intellectual property rights will become a public domain. Whereas for those who obtain a patent, they will obtain a patent certificate from DJHKI.

That is a review of the Patent Rights of Intellectual Property (IPR). Given that the terms and conditions for filing IPR patents are quite long, there is an IPR consultant agency. Hopefully this review is useful. Happy work creates intellectual work.

\section{B. ACKNOWLEDGEMENT}

University Of Indonesia

University Of Mitra Indonesia

Telkom University

University Of Mellbourne

Saitama University 


\section{REFERENCE (Based ISO 690 )}

[1] A. S. Putra And O. M. Febriani, "Knowledge Management Online Application In Pdam Lampung Province," In Prosiding International Conference On Information Technology And Business (Icitb), 2018, Pp. 181-187.

[2] A. S. Putra, O. M. Febriani, And B. Bachry, "Implementasi Genetic Fuzzy System Untuk Mengidentifikasi Hasil Curian Kendaraan Bermotor Di Polda Lampung," J. Sist. Inf. Dan Manaj. Basis Data, Vol. 1, No. 1, Pp. 21-30, 2018.

[3] O. M. Febriani And A. S. Putra, "Sistem Informasi Monitoring Inventori Barang Pada Balai Riset Standardisasi Industri Bandar Lampung," J. Inform., Vol. 13, No. 1, Pp. 90-98, 2014.

[4] Putra, Arie Setya. "2018 Artikel Struktur Data, Audit Dan Jaringan Komputer." (2018).

[5] Putra, A. S. (2018, July 17). Paperplain Fundamental Create Application With Borland Delphi 7.0 University Of Mitra Indonesia. Retrieved From Osf.Io/Pbrn9.

\section{E. REFERENCE(Based APA )}

Putra, A. S., Aryanti, D. R., \& Hartati, I. (2018, November). Metode SAW (Simple Additive Weighting) sebagai Sistem Pendukung Keputusan Guru Berprestasi (Studi Kasus: SMK Global Surya). In Prosiding Seminar Nasional Darmajaya (Vol. 1, No. 1, pp. 85-97).

Sari, D. P., Febriani, O. M., \& Putra, A. S. (2018, November). Perancangan Sistem Informasi SDM Berprestasi pada SD Global Surya. In Prosiding Seminar Nasional Darmajaya (Vol. 1, No. 1, pp. 289-294).

Putra, A. S. (2018). Paperplain: Execution Fundamental Create Application With Borland Delphi 7.0 University Of Mitra Indonesia.

Putra, A. S., Sukri, H., \& Zuhri, K. Sistem Monitoring Realtime Jaringan Irigasi Desa (JIDES) Dengan Konsep Jaringan Sensor Nirkabel. IJEIS (Indonesian Journal of Electronics and Instrumentation Systems), 8(2), 221232.

Darmawan, A., Yuliawati, D., Marcella, O., \& Firmandala, R. (2016). Sistem Absensi dan Pelaporan Berbasis Fingerprint dan SMS Gateway. EXPLORE, 7(1).

Febriani, O. M., Wahyuni, T., \& Yusuf, S. (2017). DESIGN OF WEBSITE-BASED INFORMATION SYSTEM FOR EDOCUMENT ADMINISTRASI IN THE COMMUNITY SERVICE UNIT (A Case Study at Rajabasa District). INTERNATIONAL JOURNAL OF 
COMPUTERS \& TECHNOLOGY, 16(7), 7010-7020.

Febriani, O. M., \& Wahyuni, T. (2017, October). PERANCANGAN SISTEM E-DOCUMENT ADMINISTRASI LOGBOOK PENELITIAN PADA UNIT LAYANAN DI BANDAR LAMPUNG. In Prosiding Seminar Nasional Darmajaya (Vol. 1, No. 1, pp. 187-194).

Febriani, O. M., \& Permadi, A. B. (2017). Implementasi Sistem Aplikasi Data Bimbingan dan Pelanggaran Siswa pada Sekolah Menengah Atas di Lampung Tengah dengan Metode Analisis dan Desain Sistem Terdistribusi (SSAD). EXPERT, 7(1).

Febriani, O. M., \& Ambarwati, L. (2015). PERANCANGAN APLIKASI PENGOLAHAN DATA PENJUALAN UKM KELANTING KHAS TELO DESA SIDOHARJO KECAMATAN JATI AGUNG KABUPATEN LAMPUNG SELATAN. Jurnal Teknologi Informasi dan Bisnis Pengabdian Masyarakat Darmajaya, 1(1), 77-95.

Febriani, O. M. (2015). Rancang Bangun Aplikasi Ecommercemenggunakan Freewebstore pada UKM Kelanting di Desa Sidoharjo Lampung Selatan. Prosiding Sembistek 2014, 1(02), 446-458. 